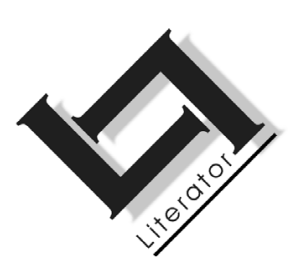

\title{
"Le plat pays" (Jacques Brel) poëties besing in Afrikaans - aantekeninge oor ikonisiteit in die oorspronklike en vertaalde chansontekste
}

\author{
B. Odendaal \& N. Morgan
}

Departement Afrikaans \& Nederlands, Duits \& Frans

Universiteit van die Vrystaat

BLOEMFONTEIN

E-pos: odenbj@ufs.ac.za

morgann@ufs.ac.za

\begin{abstract}
"Le plat pays" (Jacques Brel) poetically praised in Afrikaans notes on iconicity in the original and translated chanson texts

The authors of this article translated the well-known chanson about Flanders, "Le plat pays", into Afrikaans as part of an extensive and ongoing Jacques Brel translation project initiated in 2005. In this analysis of both the original and translated "Le plat pays" lyrics, the marked poetic qualities of Brel's chanson are laid bare, as are some semantic differences - and the implications for the analysis thereof - between source (original) and target (translated) texts.
\end{abstract}

\section{Opsomming}

"Le plat pays" (Jacques Brel) poëties besing in Afrikaans aantekeninge oor ikonisiteit in die oorspronklike en vertaalde chansontekste

Die outeurs van hierdie artikel het die bekende chanson oor Vlaandere, "Le plat pays", in Afrikaans vertaal as onderdeel van 'n uitgebreide en voortgaande Jacques Brel-vertaalprojek, wat in 2005 van stapel gestuur is. In hierdie ontleding van sowel die oorspronklike as die vertaalde "Le plat pays"-lirieke word die opmerklike poëtiese kwaliteite van Brel se chanson blootgelê, asook bepaalde semantiese verskille - en die implikasies vir die interpretasie daarvan - tussen die bron- en doeltekste (oorspronklike en vertaalde tekste). 


\section{Vooraf}

Die outeurs van hierdie artikel het in 'n vorige bespreking (Odendaal \& Morgan, 2009) aandag gegee aan die kenmerkend literêre kwaliteite van die chanson as liedgenre, asook aan Jacques Brel as toonaangewende chansonnier van die twintigste eeu. Daarna is die literêre aard van dertien van Brel se chansons, wat as eerste fase van 'n voortgesette Jacques Brel-projek in 2005 deur die artikelouteurs in Afrikaans vertaal is, uiteengesit, terwyl die aandag hier en daar ook gevestig is op vertaalstrategieë wat in die proses gevolg is.

In hierdie opvolgartikel word een van die dertien vertaalde chansons, naamlik die bekende "Le plat pays", in meer besonderhede as digterlike teks ontleed. Die fokus val veral op die verikoniserende kenmerke daarvan en word gedoen na aanleiding van 'n kernagtige uiteensetting van die begrip ikonisiteit. Eers kom die oorspronklike Franse liriek (bronteks) onder die loep, en daarna die Afrikaanse omsetting (doelteks). Laasgenoemde bied ook die geleentheid om, deur middel van 'n vergelyking met die bronteks, meer uitgebreide kommentaar te lewer op die vertaalstrategieë wat gevolg is, en wel deur benutting van vertaalwetenskaplike terminologie soos onder meer uiteengesit deur Naudé (2001).

\section{Enkele opmerkings oor ikonisiteit}

'n Nuttige begrip om die digterlike gehalte van "Le plat pays" te help beskryf, is ikonisiteit. Hoewel teoretici beklemtoon dat ikoniese tekens (as form miming meaning, of as the motivated sign) 1 omnipresent in language and verbal communication is (Nöth, 2001:18; vgl. ook Fónagy, 1999:4), word dit tog gereeld uitgesonder (bv. deur Van Zoest, 1978:104-105) as 'n besondere eienskap van die literêre en veral die poëtiese werk. 2 Of soos Bronzwaer (1990:97), in aan-

1 Soos twee van die boeke uit die reeks Iconicity in language and literature dit wil hê. Die vier bestaande titels van hierdie reeks verskyn in die lys van geraadpleegde bronne.

2 Herlofsky et al. (2005:4-5), in navolging van Bouissac (2005), meen dat dit in hierdie verband nuttig kan wees om te onderskei tussen literêre verikonisering (artificial iconicity, wat opvallend gemaak word) en talige verikonisering (natural or functional iconicity, wat konvensioneel en derhalwe minder opvallend is). Tabakowska (1999:364) onderskei op ongeveer dieselfde gronde tussen creative iconicity en lexicalized and grammaticalized iconicity. Wat die verband tussen ikonisiteit en literariteit betref, skryf Nöth (2001:24) die volgende: "(T)he principle of iconicity is in fact the common denominator of the seemingly opposite theories of literary aesthetics, the theory of literary mimesis and the theory of literary autonomy." 
sluiting by Lotman (1977), dit stel: "Poëtisch taalgebruik, actief of passief, is dat taalgebruik waarin wij streven naar maximale iconiciteit van de boodschap[.]" Dit behels taalgebruik "waarmee wij aan de opzegbaarheid van de tekens proberen te ontsnappen" (Bronzwaer, 1993:31), naamlik deur die toevoeging van 'n "Distorter or Modifier, i.e. a system of complementary iconic encoding" (Fónagy, 1999:25).

Ikone is een van die drie basiese tekensoorte wat deur die Amerikaanse filosoof en logikus Charles Peirce op grond van die verhouding tussen tekens en objekte onderskei is (vgl. Odendaal, 1997:3940; ook bv. Johansen, 2003:379). Ikone staan volgens hom in 'n relasie van gelykenis ${ }^{3}$ met die objekte waarna hulle refereer en is derhalwe die mees fundamentele tekentipe; dit het "een soort directe overtuigingskracht, een onmiddelijke, 'verleidende' werking" (Van Zoest, 1978:106). 4 Klanknabootsende woorde is maklik herkenbare en begryplike voorbeelde van ikoniese tekens, maar byvoorbeeld in die poësie kan feitlik enige talige, stilistiese, verstegniese, vormlike en tipografiese elemente ikonies benut word (Bronzwaer, 1993:2728).

3 Volgens Nöth (2001:18) het Peirce geskryf dat 'n ikoon as teken, 'n ooreenkoms vertoon met sy objek, of dat dit "partakes in its character". Tabakowska (1999:362-363) wys tereg daarop hoe subjektief, ambivalent en taalspesifiek die nosie gelykenis (similarity) is: "(I)t is ultimately based upon choice, and conditioned by particular systems of values, attitudes, ideologies, etc. In short, it is culturally determined." Vandaar beklemtoon Nöth (2001:25) dat arbitrariteit en ikonisiteit "are not a matter of either-or; one principle does not exclude the other". Trouens, Peirce het reeds beklemtoon (vgl. onder meer White, 1999:84; Nöth, 2001:19; Johansen, 2003:380) dat die onderskeidings tussen simboliese tekens (wat in 'n relasie van afspraak of konvensie tot hulle objekte staan), indeksikale tekens (wat in 'n relasie van aanwysing of aangrensendheid tot hulle tekens staan) en ikone glad nie absoluut is nie; dat elke teken eintlik kenmerke van al drie relasies bevat, en dat die kenmerke van die een of die ander relasie net domineer in bepaalde gevalle. Ten spyte van hierdie problematiek en die beperkings wat dit meebring ten opsigte van die moontlikhede van dusdanige tekenklassifikasies, bly die konsep ikonisiteit nuttig om funksionele vormgewing in literêre tekste aan te dui, dit wil sê, in retoriese sin as "verborge" geloofbaarmaking (Van Zoest, 1978:106) van (aspekte van) die teksboodskap.

Ook Herlofsky et al. (2005:4) verbind ikonisiteit met uitings wat retoriese krag besit. Ruimte ontbreek egter om hierdie aspek in enige besonderhede te verklaar. Daar word volstaan met die oorkoepelende opmerking dat dit gaan om die "demonstratiewe" en derhalwe sterker geloofbaarmakende wyse waarop talige, stilistiese en verstegniese middele benut word om een of ander "gelykenis" met die semantiese aspekte van byvoorbeeld die gedig te vertoon, sodat die "boodskap" van die gedig hierdeur medegekonstitueer én -gefasiliteer word (vgl. Odendaal, 1997:61-67 vir 'n meer uitvoerige bespreking hiervan). 
Die "triade van ikoonsubklasse" (Nöth, 2001:21) wat Peirce onderskei het, is welbekend, hoewel die grense tussen hulle nie skerp is nie, en aspekte van al drie soorte gewoonlik tesame voorkom (Tabakowska, 1999:372; Johansen, 2003:380). Kortliks kom dit daarop neer dat beeldikone - deur Peirce images genoem, maar deur Wybenga en Cloete (1992:179-180), in navolging van Van Zoest (1978:109-111), as topologiese ikone beskryf - meestal in terme van ruimtelikheid, piktorale kontoer of tipografie beskryf word. Beeldikone, die eerste ikoonsubklas, appelleer egter nie uitsluitlik aan die gesigsintuig nie (Johansen, 2003:380); klanknabootsende woorde, met die onmiddellik waarneembare similariteit wat dit met die objek van verwysing vertoon, is ook deur Peirce as images bestempel.

Die tweede subklas, diagrammatiese ikone (diagrams in Peirce se terminologie), word in terme van analoë strukture of relasies gedefinieer (Nöth, 2001:21). Hier kan 'n mens byvoorbeeld dink aan die klimaktiserende plasing van 'n kernbegrip aan die einde van 'n versreël of sin, of aan die representasie van gebeure in 'n verhaalintrige in dieselfde (chronologiese) volgorde as die gebeure in die werklikheid waarna gerefereer word (die ordo naturalis van die gebeure; vgl. Nöth, 2001:21). In vergelyking met die sintuiglike basis van beeldikone is diagrammatiese ikone dus besonder abstrak van aard; dit is tipies verintellektualiseerde en veralgemeende objekvoorstellings (Johansen, 2003:381).

Peirce se metaphors, of metaforiese ikone (die derde subklas), refereer (via die interpretante, of "idees", in die menslike gees waardeur die verwysingsfunksies tot stand kom) tipies na meer as een objek op grond van 'n bepaalde ooreenkoms tussen hulle (dit wil sê tussen hulle interpretante). Dit is dus bemiddelde ikonisiteit: "The ideas conveyed by the sign and the idea of its object are mediated by a third idea, the tertium comparationis between the tenor and the vehicle of the metaphor." (Nöth, 2001:21.) Johansen (2003:383) beskryf dié relasiekompleks soos volg: "A metaphor, according to Peirce, is a relation between two signs in which the representative character of the former is expressed through, and by virtue of, the latter."

Metaforiese ikone is eweneens kenmerkend verintellektualiseerd en abstrak, en manifesteer op die literêre terrein, byvoorbeeld op makrostrukturele vlak, in tekste wat allegories of parabolies van aard is (Van Zoest, 1978:110; Johansen, 2003:385). Van Zoest (1978:111) noem die voorbeeld van die siklisiteit in die struktuur van Gerard Reve se roman, De avonden, wat ikonies word van die verstikkende geroetineerdheid van die hoofkarakter, Frits van Egters, se daag- 
likse bestaan. 'n Ritmiese effek, byvoorbeeld die opeenhoping van heffinge om met 'n beskrewe verlangsaming in beweging in 'n poësieteks saam te val, kan as 'n voorbeeld van metaforiese ikonisiteit op mikrostrukturele teksvlak genoem word.

\title{
3. Verikoniserende elemente in Jacques Brel se "Le plat pays"
}

\author{
"Le plat pays" (oorspronklike Franse teks) \\ 1
}

Avec la mer du Nord pour dernier terrain vague

Et des vagues de dunes pour arrêter les vagues

Et de vagues rochers que les marées dépassent

Et qui ont à jamais le cœur à marée basse

Avec infiniment de brumes à venir

Avec le vent de l'est écoutez-le tenir

Le plat pays qui est le mien

2

Avec des cathédrales pour uniques montagnes

Et de noirs clochers comme mâts de cocagne

Où des diables en pierre décrochent les nuages

Avec le fil des jours pour unique voyage

Et des chemins de pluie pour unique bonsoir

Avec le vent d'ouest écoutez-le vouloir

Le plat pays qui est le mien

3

Avec un ciel si bas qu'un canal s'est perdu

Avec un ciel si bas qu'il fait l'humilité

Avec un ciel si gris qu'un canal s'est pendu

Avec un ciel si gris qu'il faut lui pardon er

Avec le vent du nord qui vient s'écarteler

Avec le vent du nord qui écoutez-le craquer

Le plat pays qui est le mien

4

Avec de l'Italie qui descendrait l'Escaut

Avec Frida la Blonde quand elle devient Margot

Quand les fils de novembre nous reviennent en mai

Quand la plaine est fumante et tremble sous juillet

Quand le vent est au rire quand le vent est au blé

Quand le vent est au sud écoutez-le chanter

Le plat pays qui est le mien 


\section{"Die plat land" (letterlike Afrikaanse vertaling met verklarende aantekeninge)}

1

Met die Noordsee as laaste woesteny

en duine soos branders om die branders te breek

en 'n paar rotse wat die getye verbysteek

en waarvan die hart ewig laagwater lê

met oneindige mistighede wat op pad is

met die oostewind - luister hoe hou hy vas

dié plat land wat myne is

2

Met katedrale as enigste berge

en swart kerktorings as lere na luilekkerland*

waar duiwels van klip die wolke pluk

met die gang van dae as enigste reis

en die reënvoortjies as enigste goeienag

met die westewind - hoor hoe begeer hy

dié plat land wat myne is

3

Met ' $n$ hemel so laag dat 'n kanaal wegraak daarin met 'n hemel so laag dat ' $n$ mens skoon nederig voel met ' $n$ hemel so grys dat 'n kanaal hom hang daarin met ' $n$ hemel so grys dat 'n mens maar moet vergewe met die noordewind wat in vier rigtings waai met die noordewind - hoor hoe kraak hy dié plat land wat myne is

4

Met Italië wat met die Schelde afkom** met blonde Frida wanneer sy Margot word ${ }^{* * *}$ wanneer November se seuns in Mei terugkeer**** wanneer die rokerige vlakte in Julie bewe wanneer die wind lag, wanneer die wind in die koring is

wanneer die wind in die Suide is - hoor hoe sing hy dié plat land wat myne is

* Mât de cocagne: 'n Tradisie wat aan die uitsterf is: as deel van die lentefeeste word 'n paal op die dorpsplein vetgesmeer; boaan word hamme en ander lekkernye vasgemaak. Diegene wat tot bo kan klim, kan hul prys afhaak.

** Die Schelde (Escaut) is 'n (bevaarbare) rivier wat in Frankryk ontspring en in die Noordsee uitmond; dit kan beskou word as 'n belangrike weg waarlangs mense, produkte en idees uit die 
Suide (by uitbreiding dus ook uit Italië) na die Noorde vervoer word.

*** Frida verpersoonlik die Germaanse of Vlaamse meisie; Margot verteenwoordig die Franse meisie - die meisie uit die Suide.

**** 'n Komplekse, nogal duistere verwysing wat waarskynlik die (Europese) einde van sowel die Eerste Wêreldoorlog (Nov. 1918) as die Tweede Wêreldoorlog (Mei 1945) betrek. "November" en "Mei" sinjaleer as maandname (soos ook "Julie" in die volgende reël) natuurlik ook bepaalde seisoene in die noordelike halfrond: November - winter; Mei - lente (en Julie somer). In totaliteit is die implikasie waarskynlik dat dit om patrone van (sikliese) herhaling gaan.

Brel teken 'n "plat land" - volgens Anthierens (1998:62) verwysend na Wes-Vlaandere - wat eerstens deur sekere natuurelemente oorheers word:

- die wind wat uit al vier rigtings waai (onderskeidelik Oos, Wes, Noord en Suid in strofes 1 tot 4), omdat die land so plat is en daar gevolglik niks is wat die winde keer nie; 5

- wolke, reën en mistigheid (strofes 1-3);

- vloeiende water (die see en sy getye in strofe 1; "des chemins de pluie" / "die reënvoortjies" in strofe 2; kanale in strofe 3; die Escaut-rivier in die slotstrofe); en

- die son van die lente ("mai") en van die somer (as die koring al uitgegroei is) wat eers in die slotstrofe vermeld word.

In strofe 2 word 'n verdere dominante element uitgesonder: die Katolieke Kerk, verteenwoordig deur die katedrale wat in daardie plat landskap die uniques montagnes is (dus as 't ware 'n verdere "natuurkenmerk"!). Die kerk word in oorwegend negatiewe terme geteken: die kerktorings is "swart" en word metafories as werklikheidsontvlugtende instrumente (as "mâts de cocagne", dit wil sê as "lere" na die denkbeeldige "luilekkerland" van Kokanje - Snijman, 1976: 678 ) voorgestel. Bowendien word die bose as inbeslote by dié instelling gesien, soos verbeeld deur die "diables en pierre" ("duiwels

5 Die "ontembaarheid", die oorrompelende aanslag van die winde word in die derde strofe beklemtoon deur die paradoksale bewering dat die noordewind "in vier rigtings waai" (“le vent du nord qui vient s'écarteler"). 
van klip", waarskynlik verwysend na die dak- of drakespuiers, dit wil sê die gemesselde geutmondings, "dikwels versier met die kop van 'n dier of draak", in die dakke van die katedrale; Odendal \& Gouws, 2005:143).

'n Interessante volgende "negatiewe" element wat in die eerste drie strofes na vore tree, is die feit dat daar so te sê geensins van mense sprake is nie, behalwe waar na die spreker verwys word met die besitlike voornaamwoordsvorm mien ("myne"). Dit is derhalwe grootliks 'n ontmenslikte landskap wat uitgebeeld word.

Tesame word hierdie "negatiewe" dominante elemente in die eerste drie strofes as 't ware deur die land "ingespan" - die herhaalde voorkoms van die voorsetsel met (avec in die oorspronklike teks) beklemtoon laasgenoemde ${ }^{6}$ - om te verhoed dat die spreker hom "le plat pays" kan toeëien (as "le mien"). Maar die verweerpogings van die land teen die spreker se strewe om die land in "besit" te neem, verswak algaande. Waar dit in die eerste strofe via die elemente nog vashou (tenir) aan sigself, kan dit in strofe twee net nog (self-) eiendomlikheid "begeer" (vouloir). In strofe 3 lyk dit of die land die (metaforiese) greep op sigself finaal aan 't verloor is, want dit "kraak" (craquer).

Die herhaalde verset van die land teen "besitname" deur die subjek word in hierdie deel van die lied op treffende wyse in bepaalde stilistiese en vormlike verskynsels "vergestalt". In terme van die ikoonsoorte wat hierbo onderskei is, sou 'n mens kon sê dat die indruk van herhaalde inspanning onderskraag of versterk word deur bepaalde metaforiese verikoniserings.

Dit word vergestalt deur die voorkoms van sekere herhaling(-metvariasie-)strukture, naamlik:

6 Van Altena (aangehaal in Brel, 2005:117-119) vertaal avec met wanneer in Nederlands. Dat hy hierdie bywoord van tyd verkies, is ' $n$ aanduiding dat hy die ontwikkeling in die liedteks waarskynlik as 'n seisoenale progressie sien: herfs en winter in die eerste drie strofes (hoewel hy dit nêrens so uitspel nie), en lente en somer (laasgenoemde met "juli-zonlicht" aangedui) in die slotstrofe. Vandaar dat daar in sy vertaalde weergawe nie sprake is van 'n (toeëiening-)stryd tussen die land en die spreker in die teks nie, soos ons dit hier interpreteer. (Oor hierdie vertaling deur Van Altena later meer.) Die probleem met die siening van die uitgebeelde voortgang in die gedig as ' $n$ seisoenale een, is dat ' $n$ mens moeilik aan die hand van die natuurgegewens in die eerste drie strofes kan aandui wanneer herfs en wanneer winter ter sprake kom. Hoe hou die volgorde van die genoemde windrigtings in die eerste drie strofes ook verband met die seisoenale opeenvolging aldaar? 
- die woordelikse herhaling van die slotreël in elke strofe wat, tesame met die telkense herhaling van die woorde "avec le vent de l'est/d'ouest/du nord écoutez-le" in die reël voorafgaande daaraan, refreinmatig funksioneer;

- die intensiewe benutting van anafore7 (bv. "Avec la/le" en "Et des/de" in strofes 1 en 2; "Avec un ciel si bas/gris" en "Avec le vent du nord" in strofe 3) en parallelismes 8 (vgl. sommiges wat reeds onder anafore genoem is, asook "pour uniques montagnes/ voyage/bonsoir" in strofe 2 en "qu'un canal s'est perdu/pendu" en "qu'il fait/faut" in strofe 3);

- woordspel (vague en vagues, tot vier maal toe, in strofe 1); en

- die intensiewe benutting van eindryme (op die paarrympatroon, behalwe ten aansien van die refreinreël en die kruisrympatroon wat in die eerste vier reëls van strofe 3 gebruik word) en allerlei binnerymvorms (alliterasies soos "de vague de dunes", "Le plat pays" en "clochers comme mats de cocagne"; akkonsonansies soos "des jours pour unique voyage" en "de pluie pour unique bonsoir"). Die klankbinding in die lied is in elk geval alreeds besonder heg as gevolg van die voorkoms van bogenoemde herhalingsfigure.

Wat voorts in hierdie verband opvallend is, is dat die benutting van anaforiese en parallelistiese strukture ' $n$ intensiteitshoogtepunt in strofe 3 bereik - juis die strofe waarin die "verweer" van die land tot die uiterste beproef word.

In verskeie opsigte bring die vierde strofe 'n wending mee. Die slegte weer slaan om in lentelike en somerse sonnigheid. Tekens van vernuwing, herlewing en groei oorheers. Daar is die beeld van Italië (waar die Renaissance sy aanvang geneem het) wat met die Escaut afkom (en waarmee die waai van die suidewind verband hou); "Frida" ontpop tot 'n "Margot"; soldate keer terug van die slagvelde af in Mei (wat aan die einde van die Tweede Wêreldoorlog dus saamgeval het met die volle deurbraak van die lente); in Julie is daar die somerse koringvelde om te geniet. Boonop is daar nou ook

7 'n Stylfiguur wat die "herhaling van dieselfde woord of woorde aan die begin van twee of meer opeenvolgende sinne, sinsnedes of versreëls" behels (Schoonees, 1970:190).

8 'n Stylfiguur "waarby herhaling met 'n klein variasie plaasvind" (Odendal \& Gouws, 2005:849). 
ander mense as net die spreker in die landskap teenwoordig, al is dit in antonomasiese vorme, soos "Frida", "Margot" en "les fils de novembre" ("November se seuns", dit wil sê die mans wat eens jong soldate was).

Die land se vroeëre verset teen toeëiening deur die spreker - die negatiwiteit van die elemente wat as 't ware opgewerp is om vereenselwiging teen te werk - sit nou om in vrygewigheid wat vreugdevol ervaar word. Laasgenoemde word onder meer geïmpliseer deur personifiërende voorstellings, soos die somervlaktes wat in die son se hitte dans, of die wind wat "lag" en "sing".

Die stilistiese en vormlike benutting van herhalings-met-variasies word voortgesit in die slotstrofe. Daardeur word eerstens die liedeenheid onaangetas gelaat. Wat voorts op hierdie wyse bewerkstellig word, is dat die spreker se vreugdevolle, liefderike vereenselwiging met sy "plat pays" op 'n klimaktiserende wyse geopenbaar, en derhalwe des te sterker geaksentueer word. Dus is daar 'n suggestie dat dit 'n liefde behels wat uiteindelik alle struikelblokke (al die inspanning van die "negatiewe" elemente deur die land) oorkom - 'n liefde wat alle ondeugde en afkerighede te bowe gaan; 'n triomferende liefde.

Die toonsetting van die liedteks versterk op subtiele maar treffende wyse hierdie (naas metaforiese ook diagrammatiese) verikonisering van die gedagte aan die oorwinning wat die spreker se landsliefde algaande oor die daarteen opgewerpte belemmerings behaal. Die melodielyn is onverwikkeld, met relatief min toonwisselings. In waarskynlik die mees bekende opname van die lied, soos dit verskyn op die 2003-uitgawe van wat as die grootste Brel-treffers voorgehou word ('n dubbel-CD-album gepubliseer onder die titel Brel infiniment), is by die sing van die eerste strofe slegs kitaarbegeleiding te hoor, waarna vanaf strofe $2 \mathrm{yl}$, swewende Martenot-golwe ${ }^{9}$ bykom, en eers in die vierde strofe ook die voller, "warmer" klank van enkele strykinstrumente. Op komplementerende (metafories-ikoniese) wyse word Brel se sang ook in die slotstrofe effens luider.

$9 \quad$ Etergolwe teweeggebring deur 'n elektriese instrument wat in ongeveer 1932 ontwikkel is, en wat bekend staan as "Ondium Martenot" of Martenot se "Ondes Musicales". Dit is een van talle instrumente wat (musikale) klank voortbring deur die "employment of electronic valve oscillators, sometimes employed singly, more often 'heterodyning' or 'beating' together, i.e. the combining of 2 electric currents of which the vibrations differ in frequency" (Scholes, 1969:178). 
Geen wonder dat Anthierens (1998:112) van "het opmerkelijk literair gehalte" van hierdie lied gewag maak nie. Naas die meermaals geuite opinie (bv. deur prof. Marcel Janssens van die Katholieke Universiteit Leuven tydens 'n besoek aan die Vrystaatse Universiteit in Mei 2002) dat "Le plat pays" / "Mijn vlakke land" die Vlaamse nasionale lied sou kon wees, het dit ook allerlei ander vorms van byval gevind. Anthierens (1998:63) noem die voorbeeld van 'n gereg (“Le râble de lapereau 'plat pays' au citron et au basilic") in die beroemde Belgiese restaurant Comme chez soi wat ter ere daarvan ontwikkel is.

'n Mens kan selfs argumenteer dat hierdie teks meer 'n gedig as bloot 'n liedteks is. By geleentheid het Brel, as 't ware ter illustrasie van hierdie aanvoeling, tydens opvoerings die lied voorgedra, in plaas daarvan om dit te sing. 10

\title{
4. Opmerkings oor die Afrikaanse omsetting van "Le plat pays"
}

\author{
My lae land11
}

1

Die see wat wag of woed, wat maak soos 'n woestyn

Die duine in sy pad wat koppig teen hom dein

Die yl-gestrooide rots wat vloed op vloed afslaan

En laaglê in die eb wat hul hul hartland waan

Die mis spookagtig kil wat altyd binnesluip

Die oostewind wat gier en gierig om hom gryp

Die lae land van my

\section{2}

Die katedraalgedoe wat hier soos berge rys

Die pad na Leeglêland waarheen die torings wys

Wyl spuierduiwels stom vanaf die dakke lag

En net die uurslag traag vooruitkom dag na dag

Die geutgegorrel van die reën wat nag wil sê

Die westewind wat tjank om als wat hy wil hê

Die Vlaand'reland van my

10 'n Opname van so 'n geleentheid verskyn op die album Brel. En scènes, wat deur Barclay uitgereik is. Brel dra die liedteks op meevoerende wyse voor: die eerste strofe sonder enige musikale begeleiding, waarna klavierspel die res van die voordrag ondersteun.

11 Gepubliseer in die CD-boekie van Van den Berg se album herman van den berg sing brel in afrikaans (2007). 
3

Die lug so laag gepak dat hemel aarde raak

Die lug so laag gepak dat mense dwerge raak

Die lug so grys gevul, riviere vloei deur wolk

Die lug so grys gevul, jy praat en asem wolk

Die noordewind slaan toe op elke koers en kant

Die noordewind slaan toe en vierendeel die land

Die lae land van my

4

Die ou herlewing wat met strome noordwaarts kom

Die meisies wat in Mei tot sjieke vroue blom

Die tyd toe seunsoldate terug kon keer as mans

Met dynsigheid wat oor die Julievlaktes dans

Die suidewind wat deur die koringakkers draf

En lag-lag kos vir sang aan voël en mens verskaf

Die Vlaand'reland van my

Ter inleiding van die bespreking van hierdie Afrikaanse omsetting moet daar genoem word dat, as gevolg van die verwikkelde, klimaktiserend-uitstellende herhalingstrukture wat in die oorspronklike Frans benut word, asook die (intensievertroebelende) weglating van leestekens deur Brel, daar twee vertalings van die laaste twee versreëls van elke strofe moontlik was. Indien 'n mens aanneem dat die voorlaaste reël telkens op 'n enjambement eindig, is die wind in elke strofe die onderwerp wat die digter se lae land vashou, begeer, kraak en (be)sing; indien die slotversreël van elke strofe egter as 'n byvoeglike bysin beskou word wat uitbrei op "hy" in die voorafgaande versreël, is dit die lae land self wat vashou, begeer, kraak en (be)sing.

In die letterlike vertaling van hierdie chanson (vgl. die jukstaposisie van Franse en Afrikaanse tekste hierbo) is aanvanklik aan eersgenoemde interpretasie voorkeur gegee. Die gebruik van die manlike lidwoorduitgang "-le" het meegewerk om écoutez-le in die sesde versreël van elke strofe telkens te verbind met die nadergeleë, voorafgaande verwysing na die wind (le vent), en nie met die eweneens manlik gemerkte [l]e plat pays in die daaropvolgende slotreël nie.

Om die twee vertaalmoontlikhede in elke strofe telkens uit te spel:

- "luister hoe hou die oostewind vas (aan) die plat land wat myne is" teenoor "luister hoe hou die plat land, wat myne is, vas";

- "luister hoe begeer die westewind die plat land wat myne is" teenoor "luister hoe begeer die plat land, wat myne is"; 
- "luister hoe laat kraak die noordewind die plat land wat myne is" teenoor "luister hoe kraak die plat land, wat myne is"; en

- "luister hoe sing die suidewind oor die plat land wat myne is" teenoor "luister hoe sing die plat land, wat myne is".

Die windverwysings in die slotstellings is telkens as metonimies verteenwoordigend gesien van wat voorafgaande in elke strofe vermeld word en wat (anafories of parallelisties) daarmee gekoppel staan.

Indien Brel telkens 'n leesteken (byvoorbeeld 'n aandagstreep, soos in ons letterlike vertaling hierbo) voor écoutez-le aangebring het om aan te dui dat wat aan die leesteken voorafgaan, as 'n geheel uitloop op wat daarna volg, sou dit waarskynlik die (aanvanklike) interpretasiekeuse verhoed het.

Die noukeurige analise van die oorspronklike liedteks met die oog op hierdie artikel het eers as korrektief gedien. Die ontleding van die teksstruktuur het naamlik laat blyk dat laasgenoemde interpretasiemoontlikheid die waarskynlik bedoelde een is, hoewel hierdie betekenis nie grammatikaal en sintakties helder geïmpliseer word nie. As gevolg van die bepaalde interpretasiekeuse, het dit ook nie by ons opgekom dat die anaforiese en parallelistiese herhalings in die eerste vyf versreëls van elke strofe, sáám met die windverwysings aan die begin van elke sesde versreël, gesien kan word as bywoordelike uitbreidings van wyse (in die vierde strofe ook van tyd) nie, naamlik op die gesegdes tenir, vouloir, craquer en chanter van die hoofsinne in die twee slotreëls van die onderskeie strofes. Die ekspressie van die (afnemende) verset deur die land teen die spreker se strewe om dit as 't ware sýne te maak in die eerste drie strofes, totdat die verset in die slotstrofe omslaan in gewillige vrygawe van genietenswaardighede deur die land, was volgens die outeurs die minder ooglopende interpretasie om voor te kies, en wel op grond van Brel se onpresiese, dubbelsinnige bewoording.

Die oorkoepelende implikasie van die huidige Afrikaanse omsetting (die doelteks, afgekort as DT) is daarom ietwat anders as dié van die (herinterpreteerde) bronteks (BT). 12 Dit gaan in die DT meer om

12 Dit is insiggewend, en versterkend van ons indruk dat Brel se formulerings in hierdie lied iewat troebel was, om in hierdie verband daarop te let dat ook Ernst van Altena in sy reeds vermelde, veel geprese - en deur Brel goedkeurend gesonge - Nederlandse vertaling bogenoemde (herinterpreteerde) sintaktiese opbou van die bronteks ignoreer. (Vgl. Van Altena se omsetting soos dit byvoorbeeld in Mijn vlakke / Le plat pays: met de vertalingen van Ernst van Altena gepubliseer is; Brel, 2005:117 \& 119.) Dieselfde geld die Engelstalige 
die opnoem van opvallende (geografiese, klimatologiese en maatskaplik-religieuse) kenmerke van die land waaraan die spreker so verknog is. (Let in verband met die vermelde verknogtheid op die herhaling van die frase "van my" - diagrammaties-ikonies geplaas in die klimaktiese eindposisie van sowel die betrokke versreëls as die verskillende strofes.) Hoewel hierdie kenmerke in die eerste drie strofes hoofsaaklik as negatief en neerdrukkend geteken word, is daar reeds iets koesterends in die gedetailleerde enumerasie daarvan (dit wil sê aanvullend tot die vereenselwiging wat deur die "van my"-refreindeel gesinjaleer word en wat getrou aan die BT-item is). Hierdie koestering ontplooi tot volledigheid wanneer die bekoorlikhede wat die land in die lente en somer bied in die slotstrofe ter sprake kom.

'n Mens kan dus wat hierdie liedomsetting betref, praat van 'n mutasie ${ }^{13}$ op makrosemantiese vlak ten opsigte van die BT, al het dit onopsetlik en slegs deels plaasgevind. Die koestering-deur-enumerasie-implikasie is in die DT bygevoeg (of liefs: sterker gemaak as in die BT), terwyl die stryd-om-besit-gedagte van die BT grootliks geskrap is. Reste van laasgenoemde is wel nog in die DT terug te vind in die personifiërende ekspressies van die "besitdrang" ten opsigte van die land by die oostewind (wat "gierig om hom gryp"; versreël 6, strofe 1), die westewind ("wat tjank om als wat hy wil hê"; versreël 6, strofe 2) en selfs die noordewind (wat "[toeslaan] op elke koers en kant"; versreël 5, strofe 3). Dit is eers die suidewind wat as vreugdevolle "gewer" optree ("lag-lag kos vir sang aan voël en mens verskaf"; versreël 6, strofe 4).

Wat die versterking, of metaforiese verikonisering, van die koesteringsgedagte (eintlik 'n wisselvorm van die besitdrang!) in die DT betref, kan daarop gewys word dat van soortgelyke herhaling-metvariasie-strukture as in die BT gebruik gemaak word, hoewel hierdie keer spesifiek met die oog op die beklemtoningseffek wat dit het:

vertaling van Morné Coetzer soos dit gepubliseer staan in die CD-boekies van Laurika Rauch se The Brel album (1997) en Karin Hougaard se Metamorph: contemporary Brel \& Piaf (1999). Die bepaalde klimaktiserende opbou in die lied word boonop in laasgenoemde opnames versteur deurdat die sing van die Engelstalige strofes op twee plekke afgewissel word met die sing van die eerste en derde strofes van Van Altena se Nederlandse vertaling.

13 Een van die vertaalstragieë wat Naudé (2001:190) beskryf en wat die skrapping van 'n BT-item en/of byvoeging van 'n item in die DT behels. 
- 'n refreinagtige slotreël in elke strofe, maar waar "[d]ie lae land" afwisselend vervang word met "[d]ie Vlaand'reland", ter wille van beter begrip by Afrikaanse gehoorlede (wat nie noodwendig almal onmiddellik die heenwysing na die "laagland" Vlaandere sal snap nie);

- die eweneens intensiewe benutting van parallelistiese en anaforiese strukture (laasgenoemde in die derde strofe, waar die kenmerkend slegte winterweerstoestande van Vlaandere op hulle felste geteken word);

- woord- en semantiese verwantskapspel, waaronder dubbelsinnighede ("duine" wat soos golwe "dein"; "laaglê in die eb"; "wat gier en gierig om hom gryp"; "westewind wat tjank om als wat hy wil hê"; "dat hemel aarde raak"; "mens praat en asem wolk"; "[d]ie noordewind slaan toe"; "ou herlewing"; "meisies wat in Mei"; "laglag [...] verskaf"); en

- die intensiewe benutting van eindryme (paarrym wat, anders as in die BT, enduit volgehou word - uiteraard met die uitsondering van die telkens alleenstaande refreinreël) en allerlei binnerymvorms (alliterasies, assonansies en akkonsonansies soos "[d]ie see wat wag of woed, wat maak soos 'n woestyn", "[d]ie mis spookagtig kil wat a/tyd binnes/uip", "die uurslag traag vooruitkom dag na dag", "met strome noordwaarts kom", ens.). Klankspelgevalle soos die volgende funksioneer so te sê klanknabootsend (beeldikonies): "geutgegorrel van die reën wat nag wil sê" en "deur die koringakkers draf [e]n lag-lag kos vir sang aan voël en mens verskaf". Soos in die BT, is die klankbinding in die DT in elk geval besonder heg as gevolg van die voorkoms van die herhalingsfigure.

Daar kan ook gewys word op die mutasie betreffende die sintaktiese verbande in elke strofe wat tussen die BT en die DT aangebring is. Die sinsdele in die eerste vyf reëls en in die eerste helfte van die sesde reël van elke BT-strofe staan in 'n bywoordelike bepalingsverband tot die hoofsinne wat telkens daarop volg, terwyl die ekwivalente bysinsdele in die DT in 'n voorwerpsinsverband tot die hoofsinsgedeeltes staan, waar laasgenoemde in die onderskeie strofeslotreëls bevat is. Die hoofsinsgedeeltes in die DT is ellipties én inversief van aard. Gevolglik lui die onderliggende sintagmatiese struktuur van byvoorbeeld die eerste strofe soos volg: "Die lae land van my is die see wat wag of woed, wat maak soos 'n woestyn; is die duine in sy pad wat koppig teen hom dein," ensovoorts. Die verbesonderende objekenumerasie, meermale in die vorm van verlewi- 
gende beeldspraak, funksioneer dan onses insiens metaforiesikonies van die koestering waarmee die land deur die spreker bejeën word. Die (sintakties "kortsluitende") ellips onderskraag op diagrammaties verikoniserende wyse die intimiteit of innigheid van sodanige bejeëning.

Ten slotte enkele opmerkings oor die beeldspraakomsettings vanaf die BT na die DT. Die eise wat die handhawing van die metriese en rympatrone van die BT in die DT gestel het, het uiteraard besondere uitdagings in hierdie verband aan die vertalers gestel. In die eerste twee strofes is die oorspronklike beelde, hoewel dikwels in leksikaal en sintakties getransponeerde 14 vorms, onses insiens tog relatief getrou oorgedra 15 na of ingeburger 16 in die DT.

Vanaf strofe 3 is in die DT egter sterker afgewyk van die beelding soos dit voorkom in die BT, hoofsaaklik met die doel om potensiële troebelhede vir die DT-gehoor op te klaar. Die kollig val hier slegs op gevalle waar gestreef is om BT-items van laasgenoemde aard in die DT toegankliker te maak.

Versreël 2 van strofe 3 bevat in die BT, naas die geykte siening van die wolkebedekking as die "hemel", eintlik geen beeld nie. Die menslike ervaring van "nederigheid" (l'humilité) onder so 'n lae, swaar en byna oorweldigende wolkehemel is in die DT konkreter gemaak deur middel van die dwergebeeld (wat ook deur Van Altena in sy Nederlandse omsetting benut is, maar wat hy in die tweede strofe van die lied geplaas het; vgl. Brel, 2005:117). In die BT bevat die reël wat direk hierop volg, 'n ietwat troebele beeld. Hoe moet 'n mens jou 'n kanaal inprent wat hom in die grysheid van mis en wolke hang (homself daaraan ophang - "qu'un canal s'est pendu")? Die DT-item ("riviere vloei deur wolk") wat in die plek hiervan gekies is, is dalk minder ekspressief, maar waarskynlik meer verhelderend,

14 Transposisie is 'n vertaalstrategie "wat 'n verandering van grammatika van die BT na die DT behels" (Naudé, 2001:190).

15 Oordrag as vertaalstrategie is die proses van onveranderde oordrag van 'n BTitem na 'n DT; soms kan die oorgedraagde BT-item as 'n leenitem in die DT beskou word (Naudé, 2001:190).

16 Inburgering of verinheemsing as vertaalstrategie kom baie ooreen met oordrag, maar word gebruik wanneer ' $n$ item met geringe veranderings uit die BT oorgeneem word ten einde die vreemdheid daarvan te verminder (Naudé, 2001:190). 
omdat dit met terme werk wat meer algemeen 17 met mekaar geassosieer word.

Ewe moeilik om te volg is die argument in versreël 4 van dieselfde BT-strofe, naamlik dat die grysheid van die bewolktheid en mistigheid 'n mens noop om "maar" te "vergewe". By die lees hiervan kom vrae soos die volgende by 'n mens op: Wie of wat te vergewe? Om watter rede? Hierdie idiosinkratiese uiting is in die DT vervang 18 met die beskrywing van 'n meer sintuiglike ervaring, naamlik hoe 'n mens weens die kondensasie van jou asem in die koue mistigheid kan dink jy "praat en asem wolk", dit wil sê hoe jy as 't ware kan ervaar dat jy deurdring is van "wolk".

Die beeld van die vierendeling van die land in die sesde reël van dieselfde strofe in die DT is 'n byvoeging wat nie in die BT voorkom nie, hoewel die BT-item craquer (kraak) wel iets daarvan gegee het. Van Altena het in sy Nederlandse vertaling van die chanson ook die vierendeling-beeld benut (vgl. Brel, 2005:11), hoewel in die voorafgaande versreël.

Strofe 4 van die BT is vol kultuurspesifieke verwysings, soos uit die drietal verbandhoudende aantekeninge by die letterlike vertaling van die lied hierbo blyk. Dit is BT-items wat tipies in 'n vertaling deur middel van vervanging en veralgemening vir die DT-gehoor toeganklik gemaak (behoort te) word.

Met die veralgemenende DT-item "ou herlewing" is nie net die tipiese Noord-Europese siening ondervang dat die lente en somer telkens uit die warmer suidelike dele van Europa noordwaarts kom nie (hier metonimies verteenwoordig deur l'Italie en die noordwaarts stromende l'Escaut), maar ook die historiese feit dat die Renaissance vanuit die Suide na die Noorde van Europa versprei het. Ook die antonomasiese, kultuurspesifieke Frida la Blonde- en Margotbeelde van die BT is veralgemenend vervang in die DT ("meisies

17 Die vertaalstrategie wat hier gevolg is, is waarskynlik as ' $n$ veralgemening te bestempel. Hier gaan dit eerstens om die veralgemening van die kultuurspesifieke item canal - so kenmerkend van die Lae Lande, maar minder algemeen in Suid-Afrika - na die algemeen bekende riviere; tweedens gaan dit om die verhelderende verplasing van die idiosinkratiese ophang-beeld met iets meer algemeen voorstelbaars.

18 Vervanging of substitusie as vertaalstrategie "behels vervanging van 'n kultuurspesifieke item (of uitdrukking) met 'n DT-item wat nie dieselfde proposisionele betekenis het nie, maar wat waarskynlik 'n ooreenstemmende impak op die doelleser sal hê" (Naudé, 2001:190). 
wat [...] tot [...] vroue blom"), met byvoeging van die DT-items Mei (eintlik verplasend ontleen aan die daaropvolgende BT-versreël) en sjieke (om as Franse leenwoord in Afrikaans nog te herinner aan die Franse meisie Margot van die BT).

Omdat Mei in die DT na versreël 2 verplaas is, was dit net nodig om in die derde versreël deur middel van die tyd daarna te verwys. Die kultuurspesifieke BT-item novembre (naas terugkeertyd vir die soldate aan die einde van die Eerste Wêreldoorlog, ook laat-herfstyd in die Noordelike halfrond) kon in versreël 3 ook geskrap word. Derhalwe kon veralgemenend verwys word na "[d]ie tyd toe seunsoldate terug kon keer as mans". Die verwysing na mans is 'n DT-byvoeging om, via die suggestie van groei van jonglingskap na volwassenheid as parallel van die seisoenale "vordering" van lentelike Mei (tweede versreël) na somerse Julie (vierde versreël), iets van 'n (hopelike) groei na groter emosionele en beskoulike volwassenheid op te vang, naamlik as resultaat van Europeërs se ontluisterende ervaring van die (Eerste en) Tweede Wêreldoorlog.

\section{Slotsom}

Tabakowska (1999:364 \& 373) wys tereg daarop dat in die literêre vertaalproses

iconicity may become problematic [...] when it constitutes [...] a particular goal-orientated strategy on the part of the original author [...]. [I]ntentional iconicity adds to the overall meaning of the text. And the 'unsaid' must be rendered in translation along 'the said'.

Want, gaan sy voort (Tabakowska, 1999:374), “... (s)ubjective factors creep in, destroying the myth of objectivity and the image of a translator as an untinted pane. As well as the dream about an objective 'translation theory' as such."

Die (self-)ontdekking via die voorafgaande literêr-kritiese ontleding dat die outeurs in die vertaling van "Le plat pays" nie net "te verwagte" subjektiewe "verskrywings" van die bronteks begaan het nie, maar ook op makrosemantiese vlak aanvanklik 'n "verkeerde", deur Brel waarskynlik onbeoogde, interpretasiekeuse uitgeoefen het (al was dit op grond van sintaktiese troebelhede in die BT), is vir ons 'n versoberende bekragtiging van bostaande sienings van Tabakowsky. Tog is daarna gestreef om die opmerklike digterlike kwaliteite van die chanson in die vertaling te handhaaf, dit selfs te versterk, en is 'n ikoniese vergestalting van daardie interpretasiekeuse daarge- 
stel. Ons vertrou 'n aanvaarbare Afrikaanse ekwivalent is vir die oorspronklike "intentional iconicity" van Brel se teks geskep.

\section{Geraadpleegde bronne}

ANTHIERENS, J. 1998. Jacques Brel: de passie en de pijn. Amsterdam: Van Veen.

BOUISSAC, P. 2005. Iconicity or iconization? Probing the dynamic interface between language and perception. (In Herlofsky, W.J., Maeder, C. \& Fischer, O. Outside-in - inside-out: iconicity in language and literature. Vol. 4. Amsterdam: Bejamins. p. 15-38.)

BREL, JACQUES. 1998. Brel. En scènes. Enregistrements inédits. Bruxelles: Barclay. [CD].

BREL, JACQUES. 2003. Brel infiniment. 40 chansons. Remasterisées haute définition. Bruxelles: Fondation Internationale Jacques Brel \& Universal Music. (LC 00126.) [CD].

BREL, JACQUES. 2005. Mijn vlakke land / Le plat pays. Met de vertalingen van Ernst van Altena. Amsterdam: Nijgh \& Van Ditmar.

BRONZWAER, W. 1990. Poëzie en iconiciteit. Forum der letteren, 31(2):93103.

BRONZWAER, W. 1993. Lessen in lyriek: nieuwe Nederlandse poëtica. Nijmegen: SUN.

FÓNAGY, I. 1999. Why iconicity? (In Nänny, M. \& Fischer, O. Form miming meaning: iconicity in language and literature. Amsterdan: Benjamins. p. 336.)

HERLOFSKY, W.J., MAEDER, C. \& FISCHER, O. 2005. Introduction: iconicity in-side-out. (In Herlofsky, W.J., Maeder, C. \& Fischer, O. Outside-in inside-out: iconicity in language and literature. Vol. 4. Amsterdam: Bejamins. p. 1-12.)

HOUGAARD, KARIN. 1999. Metamorph: contemporary Brel \& Piaf. Johannesburg: JNS Musiek. (JNSD 81.) [CD].

JOHANSEN, J.D. 2003. Iconizing literature. (In Müller, W.G. \& Fischer, O. From sign to signing: iconicity in language and literature. Vol. 3. Amsterdam: Benjamins. p. 379-410.)

LOTMAN, J. 1977. The structure of the artistic text. Trans. by Ronald Vroom. Ann Arbor: University of Michigan Press.

NAUDÉ, J.A. 2001. Vertaalkunde vandag: 'n oorsig. Tydskrif vir geesteswetenskappe, 41(3):177-194.

NÖTH, W. 2001. Semiotic foundations of iconicity in language and literature. (In Fischer, O. \& Nänny, M. The motivated sign: iconicity in language and literature. Vol. 2. Amsterdam: Benjamins. p. 17-28.)

ODENDAAL, B.J. 1997. Retoriese strategieë in die poësie van T.T. Cloete. Bloemfontein: Universiteit van die Vrystaat. (Ongepubliseerde Ph.D.-proefskrif.)

ODENDAAL, B. \& MORGAN, N. 2009. 'n Verslag oor die vertaling van dertien Jacques Brel-chansons in Afrikaans. Literator, 30(2):1-25.

ODENDAL, F.F. \& GOUWS, R.H. 2005. Verklarende Handwoordeboek van die Afrikaanse Taal. 5e uitg. Kaapstad: Pearson Education South Africa.

RAUCH, LAURIKA. 1997. The Brel album. Johannesburg: Select Musiek. (SELBCD263.) [CD]. 
SCHOLES, P.A. 1969. The Concise Oxford Dictionary of Music. 2e uitg. Gered. deur J.O. Ward. Londen: Oxford University Press.

SCHOONEES, P.C., red. 1970. Woordeboek van die Afrikaanse Taal. Deel 1: (A-C). Pretoria: Staatsdrukker.

SNIJMAN, F.J. , red. 1976. Woordeboek van die Afrikaanse Taal. Deel 6: (KLAKOL). Pretoria: Staatsdrukker.

TABAKOWSKA, E. 1999. Iconicity and literary translation. (In Nänny, M. \& Fischer, O. Form miming meaning: iconicity in language and literature. Amsterdam: Benjamins. p. 361-376.)

VAN DEN BERG, HERMAN. 2007. (H)erman van den berg sing brel in afrikaans. Johannesburg: selfuitgawe. (hvdb004.) [CD].

VAN ZOEST, A.J.A. 1978. Peirciaanse semiotiek. (In Grivel, C., red. Methoden in de literatuurwetenschap. Muiderberg: Coutinho. p. 102-114.)

WHITE, J.J. 1999. Forms of creative interaction between iconicity and indexicality in twentieth-century literature. (In Nänny, M. \& Fischer, O. Form miming meaning: iconicity in language and literature. Amsterdam: Benjamins. p. 83-108.)

WYBENGA, G. \& CLOETE, T.T. 1992. Ikoon en ikonisiteit. (In Cloete, T.T., red. Literêre terme en teorieë. Kaapstad: HAUM. p. 178-182.)

\section{Kernbegrippe:}

Afrikaanse vertaling

Brel, Jacques

ikonisiteit

Le plat pays

vertaalteorie

Key concepts:

Afrikaans translation

Brel, Jacques

iconicity

Le plat pays

translation, theory of 